\title{
The Existence of Pesantren: Implication Study of Pesantren Leadership Regeneration in Central Java
}

\author{
Imam Azro'i \\ Institut Pesantren Matahli'ul Falah Pati \\ Email:adzroie@ipmafa.ac.id \\ Isrokh Fuaidi \\ Institut Pesantren Matahli'ul Falah Pati \\ Email:fuaidi@ipmafa.ac.id
}

\begin{abstract}
Pesantren is an Islamic educational institution with a high dependency on its leader namely Kiai. The differences between competencies among their successors contributed to the decreasing in pesantren development. This research is conducted to answer the issue of sustainability in the leadership regeneration system of pesantren in Central Java, and its implications to sustaining pesantren. Data is collected using interviews, observation, and documentation. The research indicated that the regeneration system in pesantren has three typologies: genealogy, professional, and genealogy-professional. Pesantren salaf or traditional pesantren use genealogy, modern pesantren use professional, and semi-modern pesantren use genealogy-professional. The research had information also regarding how to sustain the pesantren and showed that the leader of the pesantren salaf tries to hardly keep the founding father's values particularly to be adapted in the educational curriculum. Modern pesantren use a modern managerial system to sustain their institution, while semimodern pesantren keep the development by building various educational institutions.
\end{abstract}

Keyword: Pesantren Leadership; Pesantren Regeneration; Regeneration Typology of Pesantren

\section{Introduction}

Pesantren is one of the oldest Islamic educational institutions in Indonesia that played a pivotal role in education development in Indonesia (Mahfudh, 1998). Pesantren, with the passage of time, change its existence although the intensity and the form are not the same between one another. This change has significant impacts on the existence, role, and achievement of pesantren goals, as well as the wider public view of educational institutions in pesantren (Nafi, 2007). The change in pesantren is generally very complex and cannot be generalized as their form and management system differ from one another. Sahal Mahfudh says that the pesantren's authority lies with the Kiai who is the powerful leader of pesantren. To which direction the pesantren will be brought and in what way to running the 
wheel of pesantren depend on the leadership, ability, and mindset of the Kiai that finally determine the whole atmosphere in the pesantren (Mahfudh, 1982).

Pesantren relies on the figure of Kiai as the central role model that makes it easy with regard to observing the model of particular pesantren. To identify the character of a specific pesantren is simply by looking at the figure of the Kiai as in most cases Kiai is the center of decision making. Kiai's or the leaders of pesantren are guidelines that serve as a reference for thinking, behaving, and acting in the pesantren community. Masyhud (2008) said that Kiai as the central figure of pesantren needs to explore the principles, concepts, and techniques for making educational decisions that continue to develop. The problem is the leadership style of pesantren which still uses genealogical because leadership talents are not all carried over in the genealogical. The difference in the ability to lead is sometimes far between one pesantren leader and his successor has an impact on the ups and downs of the role of pesantren in developing Islamic religious education. As long as the Kiai from pesantren is can to become a figure to carry out the pesantren's continuing mandate and carry out social roles in society, so long as that pesantren will be accepted and survive amid the community. Sahal Mahfudh (1993) described the failure of pesantren in leadership regeneration is because pesantren rarely do a massive regeneration.

Pesantren with a modern organizational system that is driven by the system will be better prepared when there is a new succession than pesantren which are still centralized by the Kiai because the pesantren's sustainability does not depend on the personality of the pesantren leader. Pesantren with centralized leadership by the Kiai will tend to be nervous when a new succession of pesantren leadership is needed because the survival of pesantren depends on a single individual, not on the people who run the system. Ansari (2015) said this succession model can be successful if the pesantren leader election system is oriented towards the professionalism of candidates in the management and leadership of the pesantren, even though the candidates prepared are their descendants or family members. However, if there is no professional generation figure, there will be problems with the sustainability of the pesantren. Some centralistic pesantren, the figure of the kiai's scholarship is inherent in the pesantren's scientific characteristics. Because 
Kiai as the leader of the pesantren also has an important role in building the culture of pesantren to form the character of the institution that can distinguish it from other institutions (Mardiyah, 2012). So, change of leaders can then reduce the characteristics of pesantren, when the next pesantren leader's knowledge differs greatly from that of the previous pesantren leader.

Mardiyah (2012) made a trichotomy of pesantren into 3 (three) namely modern pesantren, salaf pesantren (Traditional Pesantren), and modern-salaf pesantren. Salaf pesantren is pesantren which cannot be separated from the figure of a Kiai. The progress or decline of pesantren is largely determined by the figure of the kyai as a central figure in the pesantren. Pesantren and Kiai have a mutually influential relationship. Pesantren can develop because of their busy figures who can lead well. On the other hand, pesantren do not develop because of the chaotic figure who cannot lead properly (Kesuma, 2014).

The succession model of the centralistic salaf pesantren as above is not to blame. However, generally in the pesantren tradition, pesantren are the Kiai's. The Kiai and his Kiai family become the sole owner of all assets owned by their pesantren. Because of private property rights, then when the Kiai dies, the pesantren will be passed on to his heirs (Sari \& Yani, 2013).

The first thing to be done in studying pesantren is defining pesantren and describing the history of pesantren. These two things are interrelated because of the emergence of the term santri together with the emergence of pesantren as the oldest educational institution in Indonesia (Mahfud, 1999). However, the lack of an informative and trusted historical source has implications for many unclear and many speculations from researchers.

Pesantren comes from the word santri which can be interpreted as santri place. The word santri comes from the word cantrik (Sanskrit or possibly Javanese) which means people who always follow the teacher, which is then developed by the Taman Siswa University in the boarding system. C.C Berg argues that the term santri comes from the term shastru, which in Indian means a person who knows Hindu holy books or a scholar of Hindu scripture (Fatah, 2005). Meanwhile, John argues that the term "santri" comes from the derivation of Tamil which means the teacher recites the Koran. Robson said the word santri comes 
from the Tamil language "sattiri" which means people who live in a shack house or religious building (Dawam \& Ta'arifin, 2008).

There are several views that lead to the definition of pesantren terminologically. Abdurrahman Wahid defines pesantren technically, pesantren is a place where santri live. Mahmud Yunus defines it as a place for santri to study Islam. Abdurrahman Mas'ud defines pesantren refers to a place where the santri devotes most of his or her time to live in and acquire knowledge (Fatah, 2005).

Marwan Saridjo defines pesantren easily and briefly, pesantren is an Islamic educational institution that has at least 3 (three) elements, namely: Kiai who educates and teaches, santri who learn and the mosque were to learn (Saridjo, 1980). Same as Dhofier (1982) who defines pesantren as a system consisting of elements of the Kiai, santri, mosque, and boarding or dormitory. Kiai is a title given by the community to an Islamic religious expert who owns or becomes the leader of a pesantren and teaches classic Islamic books to his santri (students).

In this study, the term pesantren is defined as a place of education and teaching that emphasizes the religion of Islam and is supported by dormitories as permanent residences for santri. So the term Pesantren Kilat or Pesantren Ramadhan is not included in this study.

\section{Basic Concept of Leadership}

Leadership occurs because there are people who have weakness who need people who have strengths (Thoha, 2009). Leadership can also occur because of influence. The influence of individuals with each other is always growing. Some individuals have a greater influence on other individuals and some conditions have more influence on certain conditions. Someone can develop the ability to influence others so the leadership can be obtained. Leadership can be defined as the ability to direct followers to work together on the tasks given by their leaders. Leadership grows naturally among people who are gathered to achieve a goal in one group (Terry, 2008).

The definition of leadership is almost as many people who research and define it because the difference defines leadership based on differences in perspective or understanding the concept of leadership itself. 
The definition of leadership is almost as many people who research and define it. That is because differences define leadership from different ways of looking at or understanding the concept of leadership itself. The following are examples of definitions mentioned one by one by Ngalim Purwanto (2009):

Leadership is power (power), which is based on the nature/character of someone who has more power, usually normative (Amitai Atzioni). The leader is the individual in the group who provides the direction and coordination tasks that are relevant to the group's activities (Fred E. Fielder). Organizational leadership means the use of power and decision-making (Robert Dubin). the essence of organizational leadership is the addition of influence (influential increment) to and above the implementation of the mechanical routine routines of an organization (Daniel Katz and Robert L. Kahn). Leadership is the beginning of a new structure or procedure to achieve the goals and objectives of the organization or to change the goals and objectives of the organization (James Lipham). Leadership is the process of influencing the activities of a group that are organized towards the determination and achievement of goals (Ralph M. Stogdill). Leadership occurs in groups of two or more people and generally involves influencing the behavior of group members in their relationship to achieving group goals (Robert J. House and Marry L. Baerz).

Leadership is an art. Zainuddin \& Mustaqim (2008) said that leadership is an art to influence the behavior of people who are led to do something towards a goal that is set. Kaloh (2006) said there are 4 (four) important requirements in leadership, namely: 1) the ability to see an enterprise as a whole; 2) the ability to make decisions; 3 ) the ability to delegate authority; 4) the ability to command loyalty.

According to the Islamic view, leadership is a mandate and responsibility that is not only accountable to the members in its leadership but will also be vertically accountable to Allah SWT. The leader's accountability as stated by the Prophet Muhammad:

$$
\text { كلكم راع وكلكم مسؤول عن رعيته }
$$

"All of you are a leader and you will be held accountable for his leadership" (Bukhari). 


\section{Characteristics of Pesantren Leadership and The Existence of Pesantren}

The quality of Islamic education can be illustrated from the typology of its leaders. Ismail Raji 'Al-Faruqi underlined, "Educational leaders in the Muslim world are people who have no ideas, culture, or goals". illustration of a typology of leaders like this symbolizes passive leaders, lack of creativity, solutions, innovation, productivity and so on. in another sense, leaders who only occupy positions as leaders formally and work routinely carry on the traditions that have been running, are leaders who are counterproductive to the continuity, especially the progress of Islamic educational institutions (Qomar,2002). Islamic educational institutions should be dynamic, open, and can be agents of change. Pesantren as an indigenous Islamic educational institution in Indonesia must be able to bring change into the pesantren community and the community around the pesantren so as not to become the scapegoat of observers and stakeholders as a policy hindrance.

The pesantren community is a Kiai (ajengan, nun, or bendara) who are caretakers, teachers, and students. The pesantren management is sometimes simple in form, where the Kiai holds absolute leadership in everything, while his leadership is often represented by a senior ustadz as "Lurah Pondok/head of the pondok". Lurah Pondok has a composition of management underneath that is complete with job descriptions. The position held by the Kiai is a dual position as caretaker and owner of the pesantren. This position is the same as the position of feudal lords who are commonly known as Kanjeng on the island of Java culturally (Wahid, 2007). This position is due to the charismatic character of the Kiai, which influences the community. The Kiai is not only regarded as a leader of the pesantren, but also as a reference in everything.

\section{Methods}

This research uses a case study approach. The population of this study was 3341 pesantren in Central Java-based on data from RMI-NU Central Java. Samples were taken based on the representation of 3 (three) pesantren trichotomies according to Mardiah (2012), namely modern pesantren, salaf pesantren, and a combination of modern and salaf pesantren. The Salaf Pesantren studied in this 
study is Pondok Pesantren Salaf APIK Kauman, Kaliwungu District, Kendal Regency, Central Java Province. The Modern Pesantren studied in this study is the Pesantren Islam Modern Assalaam Sukoharjo, Central Java. The Semi-Modern Pesantren studied in this study is Pondok Pesantren Futuhiyyah, Mranggen District, Demak Regency, Central Java Province.

\section{Result and Discuss}

This research proposes a synthesis based on previous studies. This synthesis was developed from the Salaf Pesantren Leadership Model by Aedi (2005). The synthesis concludes that the regeneration system of pesantren leaders is divided into three: First, there is genealogical regeneration (Ansari, 2015; Sari \& Yuni, 2013; Mardliyah, 2012) which states that leadership succession in pesantren is based on nasab or genealogy.

Second, professional regeneration (Anwar, 2010) states that a good regeneration system in pesantren is based on a modern system that has been established in pesantren management. Third, is genealogical-professional cadre formation (Ansari, 2015) also states that pesantren-based pesantren leadership emphasizes descent but prioritizes professional personnel.

The regeneration of leaders in the Salaf pesantren, modern pesantren, and semi-modern pesantren is different from each other. Salaf pesantren tend to do regeneration based on genealogy which prioritizes heredity as the main requirement to become a leader of pesantren. Modern pesantren tend to do regeneration based on professional considerations, which prioritizes professionalism as a successor to pesantren leadership. Semi-modern pesantren tends to do regeneration with genealogical-professional considerations. Semimodern pesantren usually have many units and institutions so that they have many situations that can be used for the next successor formulation. Heredity is a major consideration in semi-modern pesantren, but the descendants must be professional personnel, educated through institutions and units in pesantren.

The formulation of the typology of the regeneration of pesantren leaders is as follows: 
Tabel I

Typology of Regeneration Pesantren Leaders

\begin{tabular}{|c|c|c|c|}
\hline SUBJECT & GENEALOGY & PROFESSIONAL & $\begin{array}{l}\text { GENEALOGY- } \\
\text { PROFESSIONAL }\end{array}$ \\
\hline $\begin{array}{l}\text { The values and } \\
\text { culture of pesantren }\end{array}$ & $\begin{array}{l}\text { Maintaining the } \\
\text { value of pesantren } \\
\text { through descent }\end{array}$ & $\begin{array}{l}\text { Management } \\
\text { performance and the } \\
\text { existence of } \\
\text { pesantren } \\
\text { priorities }\end{array}$ & $\begin{array}{lr}\text { Maintain } & \text { value } \\
\text { through } & \text { trained } \\
\text { descent } & \end{array}$ \\
\hline $\begin{array}{ll}\text { behavior on } & \text { the } \\
\text { maturity } & \text { of } \\
\text { generations } & \end{array}$ & $\begin{array}{l}\text { Instruction and } \\
\text { delegation }\end{array}$ & Consultation & $\begin{array}{l}\text { Delegation, } \\
\text { instruction, and } \\
\text { participation }\end{array}$ \\
\hline $\begin{array}{l}\text { The position of the } \\
\text { leader toward the } \\
\text { system }\end{array}$ & Highest authority & $\begin{array}{l}\text { Management system } \\
\text { above the leader }\end{array}$ & $\begin{array}{l}\text { Kiai is the highest } \\
\text { authority, but in his } \\
\text { formal institutions } \\
\text { are based on the } \\
\text { system }\end{array}$ \\
\hline $\begin{array}{l}\text { Pesantren } \\
\text { ownership }\end{array}$ & Owned by family & Foundation & $\begin{array}{l}\text { Owned by a large } \\
\text { family but several } \\
\text { small units are } \\
\text { owned by private } \\
\text { family members }\end{array}$ \\
\hline $\begin{array}{l}\text { Modern leadership } \\
\text { model }\end{array}$ & $\begin{array}{l}\text { Charismatic- } \\
\text { traditional }\end{array}$ & Rational & Charismatic-rational \\
\hline Decision making & $\begin{array}{l}\text { Top-down, } \\
\text { instructional, } \\
\text { technical }\end{array}$ & $\begin{array}{l}\text { Based on the agreed } \\
\text { job description }\end{array}$ & $\begin{array}{l}\text { Based on the job } \\
\text { description, but not } \\
\text { comprehensive and } \\
\text { caretaker at the } \\
\text { strategic level }\end{array}$ \\
\hline $\begin{array}{l}\text { History } \\
\text { succession }\end{array}$ & Family appointment & $\begin{array}{l}\text { Foundation } \\
\text { appointment }\end{array}$ & $\begin{array}{l}\text { discussed by family } \\
\text { and foundation }\end{array}$ \\
\hline
\end{tabular}

Salaf Pesantren as like Pondok Pesantren Salaf APIK Kauman Kaliwungu he strongly safeguards the values that have been put down by the founding father, even within a century of the existence of pesantren. KH. Sholahuddin Humaidulloh, caretaker of the Pondok Pesantren Salaf APIK Kaliwungu stated that: "Pesantren survives because it does not change what has been determined by funding father, like the curriculum. Kitab Kuning (Islamic Manuscript) that was studied since the first time this pesantren was established until now has not changed". This is the reason behind the existence of the Pesantren APIK Kauman Kaliwungu even though it has experienced 4 changes of leadership. The curriculum for religious studies has never expired, there are only santri adapting to different contexts in each age. 
Islamic boarding school leaders have guidelines in managing Islamic boarding schools from previous leaders so that no leader makes policies that could risk the decline of the pesantren, even boarding schools tend to be stable and develop until now.

The implication of the regeneration system in semi-modern pesantren such as Pondok Pesantren Futuhiyyah Mranggen has a different style (genealogicalprofessional) that keeps it developing until now. Regeneration carried out by the caretakers to their successors by providing separate land or institutions to be managed by their successors. This method has an impact on the successor autonomy and minimizes conflicts over the struggle for influence between family members if there is only one institution managed by many extended family members. The regeneration by placing family members in new institutions made Pondok Pesantren Futuhiyyah Mranggen develop with various choices of formal educational institutions.

\section{Conclusion}

Research on the implications of the regeneration of pesantren leadership on the existence of pesantren concludes several things Pesantren leadership regeneration in formulated in a typology which consists of three forms. The typology includes genealogical forms, namely the regeneration of leaders that prioritize heredity as a condition for leadership succession. Professional form, namely the regeneration of pesantren leaders that prioritizes individual professional competencies that are worthy of being pesantren leaders. The genealogical-professional form is the regeneration of pesantren leaders that prioritizing heredity is a condition of leadership succession, but takes into consideration the professional competence of family members. The study also found that salaf pesantren tended to use genealogical forms in the regeneration of pesantren leaders. Modern pesantren tend to use professional forms in the regeneration of pesantren leaders. Semi-modern pesantren tends to use a genealogical-professional form in the regeneration of pesantren leaders.

Implications for the regeneration of pesantren leaders in salaf pesantren in genealogical form have a risk to the successor competencies that can have implications for the stagnation of pesantren. However, salaf pesantren such as the 
Pondok Pesantren Salaf APIK Kaliwungu, can still maintain the existence of pesantren, instead of developing with an increasing number of students by staying consistent in the curriculum set by the founders of the pesantren. Implications for the regeneration of pesantren leaders in modern pesantren in a professional form run the risk of reducing pesantren culture and values that uphold transcendental factors generally. Modern boarding schools such as Pondok Pesantren Modern Islam Assalaam Sukoharjo prioritize modern management to survive and develop boarding schools. Modern management increasing service quality and make it easier to achieve the goal of pesantren organization. Implications for the regeneration of pesantren leaders in semi-modern pesantren have the risk of difficulty in choosing available cadres if many cadres are competent. Usually, if the cadres have the same competence, then the age factor and the main nasab factor will be considered. Pesantren in this form can maintain their existence and develop because they have many cadres developing other educational institutions under the umbrella of the main pesantren, usually in the same foundations.

\section{Recommendation}

Pesantren in order to maintain their existence through leadership should be able to choose the right regeneration method based on the form and the factors underlying the pesantren. Small pesantren, regeneration can be done simply in the form of genealogical but delegating cadres in functional affairs of pesantren to become professional cadres. Large pesantrens are recommended to have a systematic regeneration system. Pesantren can run modern management, but while maintaining the typical values of pesantren which are one of the important assets of pesantren.

\footnotetext{
$* * * * * * * * *$
} 


\section{Bibliography}

Aedi, N. (2017). Sistem Suksesi Kepemimpinan Pondok Pesantren Dalam Perspektif Tradisi Dan Inovasi (Studi Kasus Atas Rc-generasi Kepemimpinan Pondok Pesantren Di Wilayah III Cirebon). Jurnal Administrasi Pendidikan, $3(2)$.

Anwar, U. S. (2010). Kepemimpinan Kiai Pesantren: Studi terhadap Pondok Pesantren di Kota Jambi. Kontekstualita: Jurnal Penelitian Sosial Keagamaan, 25(2).

Ali, M. (2008). Kebijakan Strategis Pembangunan Pendidikan Islam. Jurnal Mihrab edisi III Jakarta: Depag RI. hal 52

Ansari, A. (2017). KEPEMIMPINAN PESANTREN. ITTIHAD, 13(23), 15-50.

Arifin, Z. (2015). Kepemimpinan Kiai dalam Ideologisasi Pemikiran Santri di Pesantren-pesantren Salafiyah Mlangi Yogyakarta. INFERENSI Jurnal Penelitian Sosial Keagamaan, 9(2), 351-372.

Bungin, M. B. (2008). Penelitian Kualitatif: Komunikasi, Ekonomi, Kebijakan Publik, dan Ilmu Sosial Lainnya. Jakarta: Kencana.

Ed. (2007). Metodologi Penelitian Kualitatif: Aktualisasi Metodologis ke Arah Ragam Varian Kontemporer. Jakarta: Rajawali Press.

Creswell, J. (1998). Qualitative inquiry and research design: Choosing among five traditions. Thousand Oaks, CA: Sage, 61.

Dawam, A., \& Ahmad T. (2008). Manajemen Madrasah Berbasis Pesantren. Jakarta: Lista Fariska Putra. cet. III.

Dhofier, Z. (1982). Tradisi pesantren: Studi tentang pandangan hidup kyai. Lembaga Penelitian, Pendidikan, dan Penerangan Ekonomi dan Sosial.

El-Saha, M. I. (2008) Manajemen Kaderisasi Ulama. Jakarta: Transwacana

Fatah, N. (2008). Landasan Manajemen Pendidikan. Bandung: Remaja Rosda Karya

Fatah, R. A., et.al. (2005). Rekonstruksi Pesantren Masa Depan: Dari Tradisional, Modern, Hingga Pos modern. Cet.I. Jakarta: Lista Fariska Putra

Gazali, E. (2018). Pesantren Di Antara Generasi Alfa Dan Tantangan Dunia Pendidikan Era Revolusi Industri 4.0. OASIS: Jurnal Ilmiah Kajian Islam, 2(2).

Kaloh, J. (2006). Pemimpin antara Keberhasilan dan Kegagalan. Jakarta: Kata

Kesuma, G. C. (2017). Pesantren dan Kepemimpinan Kyai. Terampil: Jurnal Pendidikan dan Pembelajaran Dasar, 1(1), 99-117.

Mahfudh, MA. S. (1982). “Orientasi Kegiatan dan Peranan Pesantren”. Makalah pada Temu Wicara Nasional di Yogyakarta. 25-28 Februari.

Mahfudh, MA. S. (1993). "Sebuah Refleksi tentang Kehidupan Pesantren". Bangsri, 21 Agustus.

Mahfudh, MA. S. (1999). Pesantren Mencari Makna. Jakarta: Pustaka Ciganjur. 
Mardiyah, M. (2012). Kepemimpinan Kiai dalam Memelihara Budaya Organisasi di Pondok Modern Gontor, Lirboyo Kediri, dan Pesantren T ebuireng Jombang. Tsaqafah, 8(1), 67-104.

Masyhud, M. S., et.al. (2008). Manajemen Pondok Pesantren. Jakarta: Diva Pustaka.

Miles, M. B., \& Huberman, A. M. (1992). Analisis Data Kualitatif (terjemahan). Jakarta: UI-Press

Moleong, L. J. (2008). Metodologi Penelitian Kualitatif. Bandung:Rosda Karya.

Nafi', M. D., et. al. (2007). Praksis Pembelajaran Pesantren. Yogyakarta: LkiS.

Purwanto, M. N. (2009). Administrsi dan Supervisi Pendidikan. Bandung: Remaja Rosda Karya.

Robbins, S. P., \& Coulter, M. (2007). Manajemen, edisi kedelapan. Jakarta: Macanan Jaya Cemerlang

Lukens-Bull, R.A. (2004). Jihad Ala Pesantren: di Mata Antropolog Amerika. Yogyakarta: Gama Media

Sari, B. I., \& Yani, M. T. (2013). Gaya dan Tipologi Kepemimpinan Kiai di Pondok Pesantren Babussalam Dusun Kalibening, Desa Tanggalrejo, Mojoagung, Jombang. Kajian Moral dan Kewarganegaraan, 2(1).

Saridjo, M. (1980). Sejarah Pondok Pesantren di Indonesia. Jakarta: Dharma Bhakti.

Siregar, F. M. (2013). Religious Leader and Charismatic Leadership in Indonesia: The Role of Kyai in Pesantren in Java. Jurnal Kawistara, 3(2).

Sugiyono. (2008). Metode Penelitian Pendidikan:Pendekatan Kuantitatif, Kualitatif, dan $R \& D$. Bandung: Alfabeta.

Suryadi, B. (2015). Generasi Y: Karakteristik, Masalah, dan Peran Konselor. Seminar dan Workshop Internasional MALINDO 4 di Bali, 22-23 Mei 2015. Diselenggarakan oleh Asosiasi Bimbingan dan Konseling Indonesia (ABKIN)

Thoha. M. (2009). Perilaku Organisasi: Konsep Dasar dan Aplikasinya. Jakarta: Rajawali Press

Wahid, A. (2007). Menggerakkan Tradisi: Esai-esai Pesantren. Yogyakarta: LKiS 